will not be so disturbing to the status quo as a reading of the preamble may lead one to believe. The same ground upon which this act may be held applicable in the broad sense might well support later legislation-given an appropriate change in the policy of the government-tending to control still further the burden of strikes and boycotts on interstate commerce by materially limiting the right to strike. (It is true that the prohibition of "compulsory arbitration" legislation might still prove a partial obstacle to complete supervision of labor relations and control of strikes.) It is not suggested that this act contains a hidden menace to organized labor; it is merely suggested that such an act as this need not inspire undue dread in the general public or in employers, nor undue hope in the leaders of labor.

\title{
PROPOSED STATUTORY CHANGES IN MARRIAGE LAW
}

The difficulties surrounding an attempt to alter statute law are notorious. Once a revision is accepted it may be impossible to procure further revision for years. Consequently a new statute should be drafted with extreme care. In failing to suggest any substantial departures from the existing law the draftsmen of the proposed Illinois Marital Relations Bill ${ }^{x}$ have failed to recognize that extreme care requires not merely rejection of changes whose value has not been demonstrated but also insistence upon changes where the existing law has proved itself inadequate.

The purpose of this note is to demonstrate that a more extensive study of the problems in the law of Marital Relations should be made before the Bill is considered by the Legislature. It will be sufficient to examine only the more striking inadequacies in the sections on Marriage. ${ }^{2}$ This is, of course, not intended to imply that the other sections are error-free. The whole Bill must be explored for desirable changes in policy and form alike. But no criticism of public policy is here attempted; suggestions are made only where results generally considered desirable are missed or the language is so ambiguous that the law remains uncertain.

Like all American marriage statutes, ${ }^{3}$ the Bill sets up an intermediate age class in which parental consent is required for a marriage. ${ }^{4}$ Although the lan-

× Illinois House of Representatives Bill No. 9rg. In the Marriage and Divorce articles there are no material changes from Smith-Hurd Ill. Rev. Stats. 1935, cc. 89 and 40 , respectively.

z Other parts are: Divorce; Uniform Marriage Evasion Law; Rights of Husband and Wife; Relinquishment of Dower and Homestead of Insane Spouse; Power over Property upon Absence or Imprisonment of Spouse; Relief to Destitute Wife or Children; Separate Maintenance.

3 I Vernier, American Family Laws 188 (I93I).

4 "Sec. 3. Age. Male persons of the age of 21 years and older and female persons of the age of $\mathrm{I} 8$ years and older may be joined in marriage. A male person who is a minor not less than $\mathrm{I} 8$ years old or a female person who is a minor not less than I6 years old may contract a legal marriage if the parent or guardian of the minor appears before the county clerk in the county. where the minor resides, consents to the marriage, makes an affidavit stating that he is the 
guage leads almost irresistibly to the conclusion that marriages by parties in this class without parental consent are not "legal," the courts are clear that they are perfectly valid..$^{5}$ For this reason the provisions of the Bill will not protect boys and girls in the intermediate group from unfortunate alliances. These provisions impose: ( $\mathrm{I}$ ) a duty on the license issuer to demand an affidavit of the applicant, and a directory power to obtain witnesses and affidavits of third parties; ${ }^{6}$ (2) a penalty for false affidavit; ${ }^{7}$ (3) a penalty for wrongful issuance of license. ${ }^{8}$ The last of these is almost worthless not only because it apparently does not apply to issuance to boys and girls in the intermediate class' but because the issuance is not wrongful unless the issuer knows of the defect and the

parent or guardian of the minor and stating that [sic] the date and place of birth and place of residence of the minor, and submits such proof of the minor's age as the county clerk deems necessary to comply with the purposes of this Act." Smith-Hurd's IIl. Rev. Stats. 1935, $^{2}$ c. 89, \& 3. For collection of statutes see I Vernier, American Family Laws $\$ 30$ (r $93 \mathrm{I}$ ). See also Brockelbank, La Formation du mariage dans le droit des Etats-Unis 24I ff. (I935).

5 Schwartz v. Schwartz, 236 Ill. App. 336 (I925); Buszin v. McKibbin, 254 Ill. App. 5 r9 (I929). See I Vernier, American Family Laws I27 (r93I); 22 L.R.A. (n.s.) I206 (Ig09). The French Civil Code once made these marriages voidable, but that rule was abrogated in 1933. Codes d'Audience, Code Civil, art. 448 (Dalloz, I934). In the framing of the Uniform Marriage Act there was an attempt to permit annulment by the parent, if the court thought it advisable or by the child, but the proposal was defeated by a vote of $x_{3}$ to $\mathrm{I} 2$, the Illinois delegate voting in its favor. 23 Green Bag 549 (rgIr). This is the provision in New York except that the court must give its approval in actions by the child as well as by the parent. Cahill's N.Y. Cons. L. 1930, c. I4, \& 7; Lazarczyk v. Lazarczyk, I22 Misc. 536, 203 N.Y.S. 29r (I924).

6 "Sec. 6 License. . . . For the purpose of ascertaining the ages of the parties and the legality of the contemplated marriage, the county clerk shall obtain the affidavit of the person applying for the license, and may, if he deems proper, obtain the affidavit of the other party to the contemplated marriage and of any other person or persons, or may examine either of the parties or any other person under oath." Smith-Hurd's Ill. Rev. Stats. 1935, c. 89, §6. Meager though this provision may seem, it goes beyond the usual powers granted license issuers. I Vernier, American Family Laws § 3 I (I93 $\mathrm{x}$ ).

7 "Sec. I4. Penalty for false affidavit. If a person wilfully and knowingly swears falsely as to any material matter in an affidavit obtained by a county clerk before the issuance of a marriage license or as to the age of either of the parties to the contemplated marriage, where their age is material, and if the county clerk is thereby induced to issue a marriage license permitting persons to be joined in marriage who are legally incapable or who have not the right to be joined in marriage, such person shall be punished by a fine of not less than one hundred dollars nor more than one thousand dollars, or by imprisonment in the county jail for not more than one year, or by both the fine and imprisonment." Smith-Hurd's IIl. Rev. Stats. rij5, c. 89,86 .

8 "Sec. I5. Penalty for wrongful issuance of license. If a county clerk knowingly issues a license for the marriage of persons who are legally incapable of contracting a marriage, he shall upon conviction be punished by a fine of not less than one hundred dollars nor more than one thousand dollars for each offense." Smith-Hurd's IIl. Rev. Stats. 1935, c. 89, § 15. There is also a penalty for performing a marriage without a license. $\S$ I7; Smith-Hurd's IIl. Rev. Stats. 1935, c. $89, \$ 15$. But this is unimportant in view of the obvious ease of acquiring a license.

9 They are not "legally incapable" of contracting marriage. This is a serious fault and should be corrected. 
improbability of his having personal knowledge is exceeded only by that of its being proved even if true..0 The use of the word "knowingly" in the definition of false affidavit is less serious, ${ }^{\mathrm{rx}}$ but experience has shown that perjury statutes have little terror for those endeavoring to evade the marriage laws. ${ }^{\mathrm{x}}$

The fact-finding duties of the issuer deserve more extended comment. Increasing complication in the formalities preliminary to marriage has not been without criticism, ${ }^{\mathrm{I}_{3}}$ but the case studies of Richmond and Hall and others have convincingly portrayed the shocking consequences of child marriages, ${ }^{14}$ and the purpose of the safeguards actually set up in the Bill is, presumably, to avoid them. The additional burden to the average license-seeker is infinitesimal in comparison.

In its present form the Bill imposes no serious obstacles to marriages between boys and girls. Not only will the license issuer rarely see more than one party (the elder, of course), but he may be satisfied with the mere affidavit of the applicant; it is too much to expect that a busy clerk will demand more. ${ }^{15} \mathrm{Al}-$ though the solemnizing officer may voice his objections, he is under no obligation to do so. ${ }^{x 6}$ If one clerk or officiant proves unyielding, the parties, educated in the ways of perjury, promptly visit another. ${ }^{27}$ Additional safeguards that might well have been incorporated in the Bill are the requirements that both parties apply for the license, ${ }^{x 8}$ that documentary proof of age be supplied, ${ }^{x 9}$ that

to This section originally applied to marriages of parties in the intermediate group and made no express requirement of knowledge in the clerk. Ill. Rev. Stats. $8445, \mathrm{p} .354$, § I0. It was, however, interpreted to require bad faith. Gilbert v. Bone, 79 Ill. 34I (I875).

Ir Witnesses will usually know whereof they speak. There is, however, the problem of "taxidriver-witnesses," especially prevalent in marriage mills. See Richmond and Hall, Marriage and the State $56 \mathrm{ff}$ (I929).

I2 Id. at 305; II Va. L. Reg. (n.s.) II3 (I925). The parties and the public prosecutor are loath to prosecute and juries loath to convict.

${ }_{13}$ "But as between the two systems of easy marriage and hard divorce and hard marriage and easy divorce, we prefer the former." 33 Albany L.J. I8r, I82 (I886). See also id. at 26r. But see id. at 319; 22 Cent. L.J. 265 (1886).

14 Richmond and Hall, Child Marriages $58 \mathrm{ff}$, 95-102 (r925). See Municipal Court of Chicago, Tenth and Eleventh Annual Report II3 (I9I5-I9I7); Hall, Child Marriages, 3 Encyc. Soc. Sci. 398 (1930).

${ }^{15}$ The usual time required for issuance of a license is not more than ten or fifteen minutes, and the clerk usually has many other duties. Richmond and Hall, Marriage and the State 42 ff (1929). At the Cook County office in Chicago the average time required is five minutes.

${ }^{16}$ In South Dakota the officiant must ascertain "to his satisfaction" the identity and age of the parties and the names and addresses of witnesses. S.Dak.Comp.L. I929, $\$$ r2I. In California he must satisfy any doubts he may have of the correctness of the statements in the license and has the same inquisitorial powers as the issuer. Cal. Civ. Code I93I, § 72.

17 This entails the loss of a fee. Some licensing officers make a habit of communicating the names of rejected applicants to other issuers in the vicinity. It might be desirable to make such a habit mandatory. See Richmond and Hall, Marriage and the State 63 (r929).

${ }^{18}$ According to Richmond and Hall this is the practice in some offices even though not required. Child Marriages I26 (I925).

${ }^{39}$ This could be limited to marriages in which there is some doubt that the parties are over the age of consent. But such a rule might lead to carelessness on the part of the issuers. Today 
the license be issued only in the county where one of the parties resides. ${ }^{20}$ An excellent statute in North Carolina provides that the issuer nust make "reasonable inquiry, ${ }^{\prime 2 x}$ and this has been construed to require a considerable degree of care. ${ }^{22}$

The control furnished by the astuteness of the license issuer and the solemnizing officer, however, is necessarily a function of the desire on the part of these persons to cooperate with the statute in avoiding undesirable marriages. ${ }^{23}$ Such officers are in a position of importance and should be chosen with care. It should not be impossible in the Bill to provide an administrative check upon the abuse of their discretion. ${ }^{24}$ In any event the fee system should be abolished. ${ }^{25}$ As has

proof of age is a frequent requirement and is available from a variety of sources in addition to the usual birth and baptismal certificates. School records, hospital records, vaccination certificates, confirmation certificates, and many others have strong probative force. Richmond and Hall, Child Marriages I32 (I925). See Cahill's N.Y. Cons. L. I930, c. I4, \& I5.

${ }^{20}$ Obviously not particularly helpful in a metropolitan community. Excellent otherwise. Section 2 of the Uniform Marriage Law has this provision but carefully extracts its teeth by permitting issuance in the county of celebration where both parties are non-resident. See Freund, A Proposed Uniform Marriage Law, 24 Harv. L. Rev. 548, 552 (rgrr).

${ }^{2 x}$ N.C. Code Ann. r935, $\$ 2503$. Violation subjects the issuer to civil liability to the parent or guardian, not to criminal prosecution. Some statutes require a "competent" or "disinterested" witness. Wyo. Rev. Stats. I93 , 68-ro6. This should be carefully enforced. See note II supra.

23 "This is the rule upon which banks act in paying checks, and surely in the matter of such grave importance as issuing a marriage license the register should not be excused upon a less degree of care." Trolinger v. Boroughs, I33 N.C. $3^{12}$, 3I7, 45 S.E. 662,664 (Ig03). See also Gray v. Lentz, I 73 N.C. 346 , 9r S.E. IO24 ( I9I7).

${ }^{23}$ See comparison of license officers studied. Richmond and Hall, Marriage and the State $47 \mathrm{ff}$ (r929). Avarice and indolence are not the only causes for lack of care. Many issuers are ignorant of the law. Many apparently consider the divorce courts a more efficient medium for avoiding matrimonial ills.

34 For instance, a statistical study giving the percentage of marriages where the ages given were just over the age of consent would be useful in estimating the amount of age falsification. A check-up might be made concerning the care taken by the issuers in exposing impediments. Similar supervision is exercised by the state over charities and boards of health. See $i d$. at 314-29.

${ }^{25}$ For the issuance of a license a fee of three dollars is collected in Cook County and one dollar in the rest of the state. Smith-Hurd's Ill. Rev. Stats. I935, c. 53, $\$ \S 35,73$. This is not so serious, of course, in large offices where wage-paid assistants are the real issuers although even here the profit motive will be effective in determining the policy of the office. The fees of solemnizing officials are left to their own business judgment except justices of the peace, who must charge two dollars. Id., \$ 59. According to Vernier all American jurisdictions impose license fees, while only fourteen expressly provide for solemnization fees. I American Family Laws Ir 3 (I93I). Notice that the fee system is objectionable only if the officer's remuneration varies with the amount of fees collected. But where it does, the fee system almost inevitably precludes care on the part of the officer. Its abolition would be the most important reform in the marriage law. 
been suggested, an officer is under great pressure to stifle what scruples he may have if a fee depends upon his complaisance and some other less scrupulous officer will be only too happy to secure the job. ${ }^{26}$ This abolition is one step toward the extinction of the much-deplored marriage mill ${ }^{27}$ from which Illinois is not free. Another step is the licensing of marriage officiants or solemnizing officials, who could then be compelled under pain of forfeiting the license, to exercise reasonable discretion in consenting to marry parties apparently under an impediment-intoxicated, very young, under coercion..$^{28}$ Still another is the requirement, already referred to, that the license be issued in the county of residence of one of the parties. ${ }^{29}$

It is generally agreed that a hasty or secret marriage is exceptionally liable to prove unsuccessful. There is ordinarily no need for haste or secrecy if no diffculties are likely to develop. In place of the ancient custom of "posting the banns," made less valuable by the growth of metropolitan communities, several states.have adopted an "advance notice" system. ${ }^{30}$ The reconsideration made possible during this waiting period will, in many cases, enable the parties to recognize the undesirability of the match. Furthermore, if the statute also provides for publication of the application or inquiries by the issuer, interested third persons may be apprised of the project and take steps to prevent it by informing the parties or the issuer of outstanding impediments. ${ }^{3 x}$ It might also be wise to make some provision for third party objection in court as is provided

${ }^{26}$ With respect to fee-paid justices of the peace it was said: "The many upright and conscientious justices, whose characters are above reproach, are prevented from exerting even the average amount of influence by the vicious system, which from its nature drives the business into the courts of disreputable wretches who are willing to barter their judgment for a paltry fee." Urdahl, The Fee System in the United States, I2 Trans. Wis. Acad. Sci., Arts, and Let. 49, 217 (1898). The advantages of the fee system-its tendency to urge officers toward efficiency and amiability, its allocation of remuneration in proportion to work done-are inundated by this àrgument.

${ }^{27}$ Richmond and Hall, Marriage and the State 84 ff. (I929).

${ }^{28}$ According to Vernier eighteen American jurisdictions have this check in some form. I American Family Laws 82 (r93r). See Ore. Code Ann. I930, 33-ro4; Wis. Stats. 1933, 245.07.

${ }^{29}$ See note 20 supra.

${ }^{30}$ Seventeen (including Hawaii), according to Vernier. I American Family Laws 54 (I93r). See Mass. Ann. L. 1933, c. 207, § I9; Mich. Comp. L. 1929, § I2708. In a few the delay is between the issuance of the license and the ceremony, making it possible for unscrupulous or benevolent officiants to avoid the statute by post-dating the certificate. In most the license is not issued until the end of the waiting period. In nearly all there is some provision for waiver of the advance notice in emergencies. Mass. Ann. L: I933, c. 20\%, $\S 30$ (in the discretion of a court or without a court when death of a party is.imminent); Mich. Comp. L. I929, § I2708, N.H. Pub. L. I926, c, 286, $\S 24$ (by court for "good cause"); Unif. Marr. and Marr. Lic. Act $\S 3$ (IgII).

3r Freund, A Proposed Uniform Marriage Law, 24 Harv. L. Rev. 548, 553 (IgIr). 
in the French Code. ${ }^{32}$ In fact it is not unthinkable to require the parties to get court consent in all doubtful cases. ${ }^{33}$

The preceding discussion is obviously not limited to the impediment of nonage. Not only does the Bill set up three impediments to a valid marriage, ${ }^{34}$ but the courts freely recognise others, ${ }^{35}$ and there are hosts which, though not affecting the legality of the marriage, may seriously jeopardize its success. Where there is a defect in one of the parties which will make the marriage void, voidable, or otherwise disastrous, it should be discovered before the wedding, not after. Some states have made a requirement of a certificate of freedom from venereal disease..$^{36}$ Although the criticisms of this requirement are not inconsiderable, ${ }^{37}$ they are not overwhelming, and it serves at least as an example of a desirable safeguard. Requirement of certificates of sanity and of freedom from tuberculosis, epilepsy, and other transmissible or inheritable diseases are not unknown..$^{38}$ Proof of death of or divorce from former spouse of a party

${ }^{32}$ Codes d'Audience, Code Civil, arts. 172-79 (Dalloz, 1934) (objection by spouse of one of parties or certain relatives). This is in line with the former rule that marriages by minors without parental consent are void. See note 4 supra. A few American states provide for third party objection. I Vernier, American Family Laws 76 (I93I). See La. Civ. Code Ann. x932, art. 106 (apparently any third person); Miss. Code Ann. 1930, § 2363 ("any interested party"); Unif. Marr. and Marr. Lic. Act $\$ 6$ (IgII) ("any person"). Great care should be taken to prevent third party objection from becoming vexatious meddling on the part of disgruntled suitors as it has become to a great extent in France.

${ }^{33}$ This would eliminate the difficulty of accurate fact finding by a clerk, considered so great by the Commissioners of Uniform Laws that they discarded provisions concerning insanity, disease, etc. 35 A.B.A. Rep. I 22 ( $(909)$. The possibility of evasion by crossing state lines will reduce the effectiveness of such a provision unless adjacent states adopt a similar rule.

${ }_{34}$ Nonage ( $(3)$, consanguinity $(\S 4)$ and insanity ( $(5)$. Smith-Hurd's Ill. Rev. Stats. I935, c. $89, \delta 83$, I, and 2 respectively.

${ }_{35}$ Prior existing marriage, Crittenden v. Hindman, 27I Ill. 577, III N.E. 488 (rgr6). Want of consent from imperfect understanding, Orchardson v. Cofeld, I7I IIl. 14,49 N.E. 197 (1898) (said to be a construction of the insanity clause). Intoxication, Barber v. People, 203 Ill. 543, 68 N.E. 93 (1903) (dictum). Duress, Short v. Short, 265 Ill. App. I33 (1932). Fraud, Lyon v. Lyon, 230 III. $366,372,82$. N.E. 850, 852 (Igo7) (dictum). See L.R.A. x $9 \times 6$ C, 690 ff.

${ }^{36}$ N.C. Code Ann. 1935, \& 2500 (a) (male only); Ore. Code Ann. r930, 33-I I 8 (male only); Wis. Stats. 1933, 245.I0 (male only; provision for free tests). See Hall, Medical Certification for Marriage $75^{-77}$ ( 1925 ).

${ }^{37}$ If the fee for such a certificate is not so high as to be oppressive, it will not be sufficient to support the apparatus required for an adequate test. It is feared that a class of shyster physicians will arise furnishing certificates upon demand. See Peterson v. Widule, $x_{57}$ Wis. 64x, 147 N.W. 966 (19I4). For this reason this requirement was defeated in Michigan. 3 Mich. St. Bar J. *I29 (1924). Instead one who has syphilis or gonorrhea is "incapable" of contracting marriage and is guilty of a felony if he tries. Mich. Comp. L. 1929, \& 12695. In New Hampshire a physician must notify the board of health if he learns that a patient with a venereal disease is about to marry. N.H. Pub. L. $x 926, \S \mathrm{Ig}$.

${ }^{38} \mathrm{~N}$.Car. Code Ann. $1935, \S 2500^{\circ}$ (a) (tuberculosis in infectious stage, adjudication of insanity); N.Dak. Comp. L. I913, $\$ 4375$ (epilepsy, insanity, tuberculosis in advanced stages, venereal diseases in male, etc.). Since these defects are less dangerous than venereal diseases, it might be desirable to require only those examinations which are comparatively simple. 
previously married could reasonably be demanded. ${ }^{39}$ To facilitate this proof there should be a central register of all divorces granted or refused in the state..$^{\circ}$

In spite of the most elaborate precautions, however, many undesirable marriages will still be contracted and the courts will continue to annul some of them. The Commissioners on Uniform Laws refused to provide rules for the annulment of marriages because they had no hope of discovering generally acceptable ones, ${ }^{4 \mathrm{I}}$ and it is not the purpose of this note to suggest substantive policy. But the statute should cover the law of annulment and especially the grounds upon which an annulment will be granted. ${ }^{2}$ The antiquated system now administered by the courts is a product of history rather than practical needs. ${ }^{43}$ Furthermore, the common law rules are not concerned with the tragic consequences of an annulment. Modern statutes provide for the limitation of attacks on marriages, ${ }^{44}$ for legitimacy and care of children, ${ }^{45}$ for the financial protection of the putative wives, ${ }^{46}$ for the exercise of discretion by the courts. $4^{47}$ There is a variety of types of curative acts..$^{8}$

39 Mass. Ann. L. I933, C.207, § 2 I (certificate of divorce); R.I. Gen. L. I923, §4164 (certificate of death or divorce).

$4^{\circ}$ Okla. Stats. I931, $\$ 4467$; Va. Code r930, $\$ 5116$ a.

$4^{x}$ Freund, A Proposed Uniform Marriage Law, 24 Harv. L. Rev. 548 (Igrr).

42 Del. Rev. Code I915, $\S 3004 ; \S 2992$ amended by Del. L. I921, p. 578; N.Dak. Comp. L. $1913, \S 4368$.

${ }^{43}$ See L.R.A. I9x6C, 690. Where the impediment was "canonical," recognized only by the ecclesiastical courts (consanguinity, etc.), the marriage was only voidable, but where the impediment was "civil," recognized by the temporal courts (fraud, duress, etc.) the marriage was void. A more rational rule would be this: Marriages are void where it is to the advantage of society to override the wishes of the parties (consanguinity, bigamy, etc.), voidable where it is expedient to permit the parties to decide their own fate (fraud, duress, etc.). Other good systems might be devised, but the changes brought about by the courts have been confused and incomplete.

44 Fourteen, according to Vernier. I American Family Laws 280 (I93I). See Cal. Civ. Code r93I, $\$ 83 ;$ N. Dak. Comp. L. I9I3, $\$ 4369$.

45 Section 20 of the Bill makes legitimate the children of persons who "attempt to contract" marriage. Smith-Hurd's Ill. Rev. Stats. I935, c.89, § 17 a. This wording is unfortunate because it might not include a ceremony where one of the parties is coerced or one knows of the defect. Better is, ".... issue of marriages declared null in law shall nevertheless be legitimate." Mason's Minn. Stats. I927, 8579. The German and Canon laws provide for legitimacy of children of a void marriage only if one of the parties was bona fide. Ayrinhac, Marriage Legislation in the New Code of the Canon Law 278 (IgI8); Germ. Civ. Code $\$$ I699 (trans. and ann. by Wang, 1907). But the German code qualifies this rule by a right in the child to demand maintenance during his father's life as though legitimate, even though neither party was bona fide. $I d ., \S 1703$.

${ }^{46}$ Conn. Gen. Stats. I930, 85188 ("as in divorce"); N.J. Comp. Stats. Igro, p. 2035, $\$ 25$ (same section for divorce and annulment).

47 Popular pressure has forced lower courts to assume this power. For instance, since no one will appeal, marriages by boys and girls in the intermediate category are constantly being annulled with impunity.

${ }^{48}$ See I Vernier, American Family Laws 80 (I93I). Most of these are vague and do little more than destroy the value of the clause abolishing common law marriages. The statute 
Similar problems are raised by the abolition of common law marriages.49 This move was inspired not so much by censure of those participating as by a desire to eliminate uncertainty..$^{50}$ Yet American legislators have remained, for the most part, unconcerned with the plight of women and children involved in these unorthodox alliances..$^{5 x}$ Awards for workmen's compensation and soldiers' bonuses might be desirable in spite of lack of marriage lines, ${ }^{52}$ if only to relax the pressure on the relief rolls.

Moreover, even where there is a marriage there is frequently great difficulty in proving its existence and validity. ${ }^{53}$ The courts have partially surmounted this difficulty by presuming that an apparently matrimonial relationship is indeed licit and by putting the burden of proof on him who attacks it.54 As an aid to proof there should be central registration of all marriages in the state, ${ }^{55}$ as well as the central registration of divorces previously suggested. ${ }^{6}$

should, however, expressly validate marriages entered into bona fide by the parties but celebrated by an officiant without authority. Unif. Marr. and Marr. Lic. Act $\$ 24$ (Igrr). It should also validate marriages void at inception because of an impediment which has later been dissolved. See Mass. Ann. L. 1933, c. 207, $\$ 6$ (bigamous, at least one party bona fide).

49 Section I8; Smith-Hurd's Ill. Rev. Stats. 1935 , c. $89, \$ 4$.

so See Richmond and Hall, Marriage and the State 293 (I929); Jacobs, 4 Encyc. Soc. Sci. 56 (193I). These are not strong authorities for the proposition stated and there are many declarations tending to the contrary. See quotations in Koegel, Common Law Marriage $167 \mathrm{ff}$. (I922). It is difficult to support a contrary policy, however. The courts have gone to extraordinary lengths to find common law marriages where possible. See Travers v. Reinhart, 205 U.S. 423 ( 1907 ); Johnson v. Dudley, 3 Ohio N.P. I96 (r8g6). And they have generally held licensing statutes directory unless clearly mandatory language was used. Heymann v. Heymann, 218 Ill. 636, 75 N.E. I079 (1905); Meister v. Moore, 96 U.S. 76 (1877); L.R.A. I9I5E, II3 ff.

sI But see Ore. Code Ann. I930, 49-1817, r8r8 (illegitimate child, and unmarried woman who has lived with unmarried employee for one year, entitled to workmen's compensation); Cal. Gen. L. I93I, act 4749, $\S \mathrm{I} 4$ (all those dependent in fact and members of household of employee entitled to workmen's compensation).

sa "... We see no escape from the conclusion that this unfortunate appellant cannot be awarded compensation from the accident fund. . . . " Meton v. State Indust. Ins. Dep't, I04 Wash. 652, 658, r77 Pac. 696, 699 (rgrg). See 39 Yale L.J. 9I7 (r930).

53 If the officiant neglects to register the certificate, there is no record of the marriage. See Richmond and Hall, Marriage and the State 295 (1929). The Bill partially avoids this danger by fixing a penalty for not registering the certificate. § I 7; Smith-Hurd's Ill. Rev. Stats. I935, c. $89, \$ 16$. A duty should be put upon all issuers to follow-up a license not returned by inquiries of the parties or of the officiant, if known.

If third persons wish to prove marriage, they may be seriously handicapped by ignorance of the exact county of celebration. There is similar difficulty in proving a prior divorce or death of a prior spouse.

54 Potter v. Clapp, 203 Ill. 592, 68 N.E. 8I (r903); Crysler v. Crysler, 330 Ill. 74, I6I N.E. 97 (1928).

5s See Seventy-sixth Annual Report on the Vital Statistics of Massachusetts for the year I917, Commonwealth of Mass., r919, p. 47, quoted in Richmond and Hall, Marriage and the State 294 (1929). Eleven purposes for such a registration are listed.

$s 6$ See note 40 supra. 
The sections on Marriage were selected for detailed discussion because their problems are principally of form and expression rather than policy. The problems in Divorce and Husband and Wife, equally important, more frequently involve conflict on fundamental social philosophy. But they should be reviewed in somewhat the same manner. Examples of these problems leap to the tongue. What shall be done to eradicate the migratory divorce, with respect both to granting them and to recognizing those granted in foreign states and countries?57 Would there not be a great improvement in the administration of family law if the Domestic Relations court were given more extensive jurisdiction and greater discretion? ${ }^{38}$ The present grounds for divorce are neither adequately planned as a matter of policy nor carefully enough drawn as a matter of form. ${ }^{59}$

With the rise of the view of unhappy marriages as a social wound and with the decay of the guilt theory of divorce comes increasing need for revamping the laws of marital relations. Product of an outworn social philosophy, they are obsolete and inadequate.

57 See Walton, International and Migratory Divorces, 2I IIl. L. Rev. 435 (I927); Beale, Haddock Revisited, 39 Harv. L. Rev. 4I7 (r926); Goodrich, Matrimonial Domicile, 27 Yale L.J. 49 (IgI7); 2 Vernier, American Family Laws \$ 89 (I932).

${ }^{58}$ See 5 Encyc. Soc. Sci. 197 (I93I); Waite, Courts of Domestic Relations, 5 Minn. L. Rev. I6r (I92I); Zunser, The Domestic Relations Court, I 24 Ann. Amer. Acad. Pol. \& Soc. Sci. II4 (I926); Hoffman, Courts of Domestic Relations, 8. J. Crim. Law \& Crim. 409 (IgIg).

${ }_{59}$ Sec. 58; Smith-Hurd's Ill. Rev. Stats. 1935 , c. 40 , $\S$ r. See Brown, The Law and Procedure in Divorce, I3 Law Notes I28 (rgog); Holbrook, Divorce Laws and the Increase of Divorce, 8 Mich. L. Rev. 386 (rgro); Herbert, Holy Deadlock (1934) (a bitter popular treatment). Cf. Williams, Divorce Legislation Needed, 8 Va. L. Reg. 397 (I922). 